\title{
Bob Tollison was a good sentence
}

\author{
Robert E. McCormick ${ }^{1}$
}

Received: 31 October 2016/Accepted: 31 January 2017/Published online: 27 February 2017

(C) Springer Science+Business Media New York 2017

I gave this eulogy/lecture a title because Bob loved titles. The title is "Bob Tollison was a good sentence." Like most of his titles, it may or not make sense at some point.

Bob Tollison had a love affair with the metaphor. He spoke in riddles, symbols, and metaphors. It almost drove you crazy at times even while it challenged and educated you. He never used two words when one might do. He wanted you to explore his brain with him, and those short declarative sentences (more on that later) were his invitation. Caveat emptor was clearly in order.

Intellectually, you all know that Bob was bigger than life. But underneath that giant was a gentle, kind, humble, most decent man. He liked people, almost all of them, and no matter your education, pedigree, standing or stature, he treated you with a calm peaceful presence, except when he hadn't had his morning cup of coffee. He could get mad, and it wasn't pretty, but age and wisdom tempered that, some.

Early last Monday morning in one short Tollisonian sentence from his lovely daughter April, all our lives were permanently changed for the worse. "Dad died", she said on the phone. I lost a father, a brother, a friend, a poker pal, a colleague, a coauthor, a fellow football fan, and an employee. Each of you lost something special too.

Bob was imperfect, as are we all. But he didn't dote on that. For instance, take his abominable hand writing; please, take his handwriting. In fact, the only good thing about his death is that his handwriting died too. I can't tell you how many times he walked into my office with a yellow piece of paper in his hand and asked ME to read HIS handwriting. I would just look back at him and laugh. He recognized his traits and did not fret. In some sense, he was the embodiment of the Nirvana Fallacy, what I call the Parable of the Bear. Bob realized in life that you don't have to outrun the bear, you just have to outrun whoever else the bear is chasing. And that is how he lived his life, never trying to be perfect, just better.

Bob taught less with his words and more with his deeds. Some examples:

Robert E. McCormick sixmile@clemson.edu

1 College of Business, Clemson University, Clemson, SC, USA 
- he went to work early, like the farmhand he really was, seven days a week.

- he never asked you to do something he wouldn't do or hadn't already done himself.

- he was neat, almost freakishly:

- he read every email he got, every one. And then promptly deleted them. Monday, as I was trying to get some contact info for Anna to notify friends of his passing, I went into his Outlook email. There was not a single email there. I suspect nobody else on earth has an empty inbox. Bob was that rare and neat.

- the top of his desk never had anything on it except a trove of dull pencils, a few pens of different sorts and colors, a single yellow pad, and whatever book or paper he was reading at that exact time.

- after dinner at his house with Anna, as soon as he could reasonably get up from the table, he went into the kitchen and started washing dishes or stacking the dishwasher. The half life of a dirty plate in their kitchen was seconds, not minutes.

- riding in his car or truck, neat, clean, and not a single piece of paper, nor an umbrella, nor a baseball cap, not a dog hair, nothing. Simple and neat.

Speaking of trucks, let me remind you of Bob's vehicle when he went to Washington with the Reagan administration to be Director of Bureau of Economics at the Federal Trade Commission. It was a 1978 or '79 Dodge half ton pickup. the ugliest tan you ever saw. Three-speed manual transmission on the column. Rubber mat floors. Plastic bench seat. Long bed. Roll-down windows, no AC, not even a radio. And one Libertarian bumper sticker. Did I say simple?

Dogs. You can learn almost all you need to know about Bob and Bob and Anna, by noting the names of their dogs:

Nevada, the three-legged Golden Retriever

Utah, the rambunctious Golden

Cheddar, the rescue Golden

Scout, the loving, loyal Boykin

Jim, an adorable pound dog millionaire, almost dachshund

and Sister, the equally adorable pound dog millionaire nearly dachshund

Bob was a classical liberal, laissez faire kind of person. Bob Ekelund is either smiling or crying as I say laissez faire because he knows more than anybody exactly what that means, and he knows I don't. In fact, he is probably going to give a lecture after this ceremony on the first half of laissez faire, laissez. Because, as I am sure he will say, you can't understand anything much until you understand laissez.

Bob cared very little what you thought of him, and he let you be. Almost never judging you. He could and would often point out things you said or did, but he would stop before he said, "stupid" or "ignorant" or "pathetic". And he rarely if ever said, "can you believe." or words like that. He would point out things and let you judge. He was what Fox says but isn't. He reported, and let you decide. I can say that I know no one who judged others less. What a person he was.

You could see Bob through his commas. A long time ago, he and I would fight about comma placement. Yes, that is what academics do. He would put them where they didn't belong and take them out where they did, at least as I saw the world. The young, impetuous, brash, loud, outspoken crazy me would go and get the MLA or Chicago Style Manual and read the rules to him. I might as well have written in Fortran or Arabic. He 
didn't care. He said put a comma where you pause when you speak and don't put one where you don't. Simple, easy, and Tollison.

Monday, when I took the duty of alerting some of Bob's friends and our closest Clemson folk about his passing, I was quickly inundated with Tollisonian short replies of regret and loss. Skip Sauer said this then, and it summarizes Bob's gentleness and greatness, "Bob was the favorite professor of many students, including two of my kids. Although he had a huge intellect and was highly accomplished he never talked down to anyone. He was a great colleague."

That was Bob; even though he almost always knew more than you, or was smarter than you on some point, he never looked down. He always wanted you to find your own way, your own greatness. He led in a quiet simple powerful way that is rare and almost unique. We can learn from him even in his passing.

I suspect that part of Bob's wonderfulness came from his family, his Presbyterian upbringing in Spartanburg with his dutiful and diligent parents that he spoke so infrequently but lovingly of. He was proud, very proud, of his dad's honest hard work at Spartanburg flour mill. To Bob, to work hard in your situation was your greatest achievement. No matter if you were born on third base or in the dugout, you could work hard and be proud. To him, you shouldn't pay much attention to where you were but where you were going.

Mike Maloney has penned a wonderful short insight into the person of Bob on his website. Many others have as well. I commend these to you when your day gets long and you pine for just a moment of Tollisonism. Read those and he will appear. I promise. Bob lives and will live.

Its not my job nor could I do it if it were to bring closure and peace to Bob's family. His incredible wife Anna. Bob once said, and he meant it, that when somebody asked him what he was going to the coming Friday night, "I am in charge of production. Anna is in charge of consumption. We specialize." His two children April and Mark who lost so much on Monday. Rich and Annabel, Sarah Jane, Katie and Zach. He had a deep love and affection for you all. Often through his own method, his deeds, and probably not as much as you would have liked maybe, his words.

Bob was a competitive guy who relished the thought of a game. We played poker, we wagered on all sorts of silliness, we pitched pennies across the office suite and out his third floor window onto an 18-wheel trailer parked behind Sirrine Hall. One summer in Blacksburg, I think it was 1980, I was there through Bob's generosity at the Public Choice Center, and Mike would come up often to work together with us. We went out to eat a lot at a mall there, Chinese almost always. Bob had spicy Hunan fish every time. And every time, we would walk out into the mall after the meal and bet $\$ 5$ or $\$ 10$ on who had the lowest blood pressure. There was a blood pressure cuff machine there, and we did it all the time.

After that we would go to the bookstore and stroll. He loved to stroll the library journal and book stacks. He would come to my office and say, let's go to the library and see. But I wander. On those nights in Blacksburg when we didn't play "who's got the lowest blood pressure" we would often go the philosophy book section. The game was, all of us would take turns reading a sentence or phrase from a philosophy book out loud to the others, and if you laughed, you had to give the reader $\$ 5$ or $\$ 10$. Bob was competitive, and he loved the game. He wanted life to be fun, and he wanted to share his fun with you. He was fun and funny. I loved him. He gave a lot of himself to me, often when I wasn't worthy.

Back in the day before email and text, I once offered my apology in a letter to him, and two days later I got back a note from him saying, thanks, but it was his fault as much as mine. 
I am going to close soon, but I can't not tell this story. Bob was not a tech savvy guy. He never learned to use a fax machine. Only recently did he learn to type, one or two fingers, and do email. His cell phone was a 1990 s' Motorola flip phone, and when he used it he turned it on and off. He thought it was like one of those old cordless land line phones that you had to turn on and off to use. So, when he would call you on his cell, rarely and only when he was on the road, and you didn't answer, he would leave a voice mail. "Bob this is Bob." He called me Bob. Even if you called him back within two minutes, you would get his voice mail, for the instant he hung up his call to you, he turned his cell phone off. I mean he turned it off. You couldn't call him. I sometimes wondered if he hid behind his facade of techno incompetence to maintain his privacy. Bob was a private person.

This is the same person who loved the short turn of a phrase. Bob was a Hemingway scholar; in fact, he was a true scholar of many things past economics. And he loved to speak of Hemingway's friend and antagonist, "F. Scotch Fitzergerald". And then he would smile, briefly, and move on.

Here are the titles of a couple of his papers,

"Give 'em and inch and they'll take a kilometer."

"Legislatures."

"Legislatures as Taxicabs."

"Legislatures as Unions." Bob had a thing about legislatures.

"Sportometrics", a word he made up.

"Breakfast at the Federal Trade Commission."

"Toenote to a Footnote" with his first Ph.D. student, Mark Crain.

As I prepared myself to give this eulogy I went through all sorts of contortions about what was the right thing to do. Should I talk about Bob's incredible academic achievements, and I decided, no. Others could and would do that better. Should I try and write this like he would have, and I decided there was no way I could do that because I simply wasn't good enough. And then I decided to do what I am sure he would have wanted me to do but would have never asked or told, "just do whatever you think is right."

No eulogy to Bob Tollison is complete without pausing to note the death of Team Tollison too. By Team Tollison I mean Bob AND Anna. Virtually everything that Bob did and accomplished was not him alone. Anna was there, sometimes in the background, but often right there. And Bob not only knew this but recognized it, often, to all of us. He knew they were a team and that played a vital role in their affairs and business. Anna managed Bob, but more, she was part of his conscience and his soul. She kept his trains running on time, and when he wanted or needed help she was there, always. They were married 40 years ago this past spring, and all that you see or read about him was in part her too. Synergy is defined as the sum being greater than the parts. That was Team Tollison. I will miss it.

So I close by explaining my title, "Bob was a good sentence."

I think I mentioned that Bob was a deep scholar of Hemingway, and a true fan. He said to me countless times, "simple declarative sentences." We talked a lot about the characters in Hemingway's books, but more so about the way he spun a story and his writing style. And I suppose Hemingway was his muse on writing with a pencil.

There came a time when I was down and out and Bob came over to my house. He gave me his own thin hardback copy of Hemingway's A Moveable Feast. I note he had paid \$6 for it in a used book store. If Bob was anything, he was frugal. Bob said to me that this book had helped him work through what he called "contretemps." He said it might help me like it helped him. 
In that book Hemingway talks of sitting in a café writing, in pencil as he always did, and says, "on a good day, I write three good sentences."

In life we get a few good friends, our sentences. Bob Tollison was a good sentence.

A sadness overcomes me and I don't know what to do. But for now, I think I will go drink a glass of Chardonnay. Cheers to you Bob Tollison with love.

Bobby McCormick

October 28, 2016 